\title{
Households' dependence on community forest and their contribution to participatory forest management: evidence from rural Ethiopia
}

\author{
Tsegaye T. Gatiso ${ }^{1,2}$ (D)
}

Received: 28 March 2017/Accepted: 15 September 2017/Published online: 3 October 2017

(C) The Author(s) 2017. This article is an open access publication

\begin{abstract}
In recent decades, there has been a major shift in natural resource conservation policies in developing countries, and community-based natural resource management has become the integral part of the policies. Nonetheless, the link between the local communities' dependence on forest resources for their livelihood and the likelihood of the success of community forest management has been understudied. Thus, this study investigates how forest dependence influences the contribution of local communities to the management of community forest, using the data collected from 190 households participating in community forest management in rural Ethiopia. It was found that the sample households derived almost $38 \%$ of their annual income from community forest. Moreover, results from mixed effects linear regression models show that forest dependence promotes contribution to collective action in the management of community forest. When households derive more income from the community forest relative to their total income, they contribute more to the management of the community forest. This suggests that the more the households depend on the community forest for their livelihood, the more they value the resource and the more they participate in the management of the forest. Thus, the results underline that the success of local communities in managing community forest may be significantly influenced by their level of dependence on the resources from the forest.
\end{abstract}

Keywords Collective action · Community forest management · Forest dependence $\cdot$ Ethiopia $\cdot$ Africa

JEL Classification Q15 - Q23 · Q50

Tsegaye T. Gatiso

tsegaye_gatiso@eva.mpg.de

1 Max Planck Institute for Evolutionary Anthropology, Deutscher Platz 6, 04103 Leipzig, Germany

2 German Centre for Integrative Biodiversity Research (iDiv), Deutscher Platz 5e, 04103 Leipzig, Germany 


\section{Introduction}

Rural households in the developing world derive significant part of their livelihoods from forest resources (Adhikari et al. 2004; Adhikari 2005; Sunderlin et al. 2005; Mamo et al. 2007; Babulo et al. 2008, 2009; Appiah et al. 2009; Gobeze et al. 2009; Gatiso and Wossen 2014; Wunder et al. 2014; Dash et al. 2016). ${ }^{1}$ It is also well documented that the rural poor obtain major part of their household income from natural resources than their better-off counterparts (Narain et al. 2008; Gatiso and Wossen 2014). Moreover, studies show that the major part of the forest income comes from natural forests (Angelsen et al. 2014). Nevertheless, this crucial resource has been continuously diminishing from time to time (FAO 2010, 2015), and hence, sustainable management of forest resources has become an important agenda both in the academia and policy arena.

In developing countries, forest resources were primarily managed through command and control approach till early 1970s (Charnley and Poe 2007). Nonetheless, the centrally controlled protectionist approach was reported to fail to conserve natural resources in general and forest resources in particular in some contexts (Gibson and Marks 1995; Dietz et al. 2003; Wells and McShane 2004; Harrison 2011). The reasons for the ineffectiveness of such approaches could range from their being expensive to implement to their crowdingout effect on pro-conservation behaviour of the local resource users (Ostrom 1999; Cardenas 2000).

In recent decades, however, the focus of conservation policies has shifted towards approaches that involve local communities in natural resource conservation (Charnley and Poe 2007). The participation of local communities in forest management could have three major advantages. First, community participation gives the opportunity to reconcile the two sides of the conservation equation: people and nature. For centuries, the local communities have been living in and around conservation areas and have been collecting resources from those areas before they were declared as protected areas. Thus, taking the resource away and restricting or denying access to the resource may adversely affect the welfare of the local communities (e.g. West and Brechin 1991; Kapoor 2001; Narain et al. 2008; Babulo et al. 2008; Gatiso and Wossen 2014; Wunder et al. 2014; Angelsen et al. 2014), and hence, these approaches may be considered as inhumane and unethical (Brechin et al. 2002). Further, exclusionary measures may resent the local communities and deepen the conflict between the conservation authorities and the local communities (Wang et al. 2006; Andrade and Rhodes 2012). Second, the involvement of local communities in nature conservation may reduce the cost of conservation (Rahut et al. 2015). It also makes targeting illegal and unsustainable resource uses easier for conservation authorities and makes it difficult for illegal users to use local villagers to elude arrest and incarcerations. Third, community involvement in forest management may increase the rate of compliance of locals with the rules and regulations of conservation areas. For example, Andrade and Rhodes (2012) assert that community participation in the decision making process of the conservation areas has positive and strong effect on the compliance behaviour of local communities with the regulations of the protected areas. Similarly, Persha et al. (2011) found that there is a strong positive correlation between the level of participation of local communities in decision making process and conservation outcomes. Moreover, Gobeze et al. (2009) reported that community-based forest management effectively reduces forest degradation.

${ }_{1}$ For example, in Ethiopia almost $89 \%$ the total national energy consumption comes from biomass (Geissler et al. 2013). 
However, the success of the participatory approach in general and community-based conservation in particular substantially hinges on the willingness of the local communities to participate in the collective action, in addition to several factors such as the presence of clearly defined boundaries, control over the resource, presence of appropriate rules, group size and others (Ostrom 1990; Pagdee et al. 2006; Cox et al. 2010; Yang et al. 2013). Recently, Schnegg et al.(2016) reported that equality in cost and benefit sharing among the members of the community also affects the effectiveness of the community management. Nonetheless, relatively little has been known about the role of resource dependence on the ability of individual members of the local communities to contribute to the management of the common pool resources. Some studies suggest that the extent to which resource users depend on the common resource for their livelihoods is an important condition which facilitates collective action in the management of the commons (e.g. Wade 1988; Ostrom 1990). Further, Lise (2000) and Heltberg (2001) point out that the common pool resource users are less likely to participate in collective action when the benefits obtained from the resources are less. Most of these studies explored the relevance of resource dependence for the effectiveness of community-based resource management at community level, and individual level studies that explore the effect of resource dependence on individual's contribution to collective action are scant.

In commons dilemma (where individual interests may be at odds with the group interests), however, emphasis should also be given to individuals' (households') contribution to collective action. Hence, this study investigates how resource dependence for livelihoods at household level facilities or impedes households' contribution to community forest management. Specifically, the study investigates the effect of forest dependence on households' self-reported labour contribution to patrol through the community forest in rural Ethiopia. The resource dependence could lead to two contradictory effects on the success of the commons management. On the one hand, heavy dependence of the local communities on resources from the community forest may lead to degradation of the resource, making the approach ineffective to conserve the resource. On the other hand, dependence on the resource may induce people to attach more value to the resource and contribute more to the management of the community forest. This study follows the second line of argument and investigates how community forest dependence may lead to more or less contribution to collective action. The study makes an important contribution to natural resource conservation policy discourse (mainly community forest management) by investigating the role of forest dependence on households' contribution to collective action for the management of community forest in rural Ethiopia.

\section{Methods and materials}

\subsection{Study site and context}

The study was conducted in rural Ethiopia, specifically in Dendi district of Oromia regional state. The area is located within the altitude ranging from 1700 to $3200 \mathrm{~m}$ above sea level (see Fig. 1).

The community forest in the study area (Chilimo-Gaji community forest) is one of the few montane forests in the country (Mohammed and Inoue 2013). The forest cover in the study area declined by more than $70 \%$ from over 22,000 ha in early 1970 s to 5800 ha in mid-1990s (Bekele and Bekele 2005). Hence, it was chosen as one of the priority areas to 


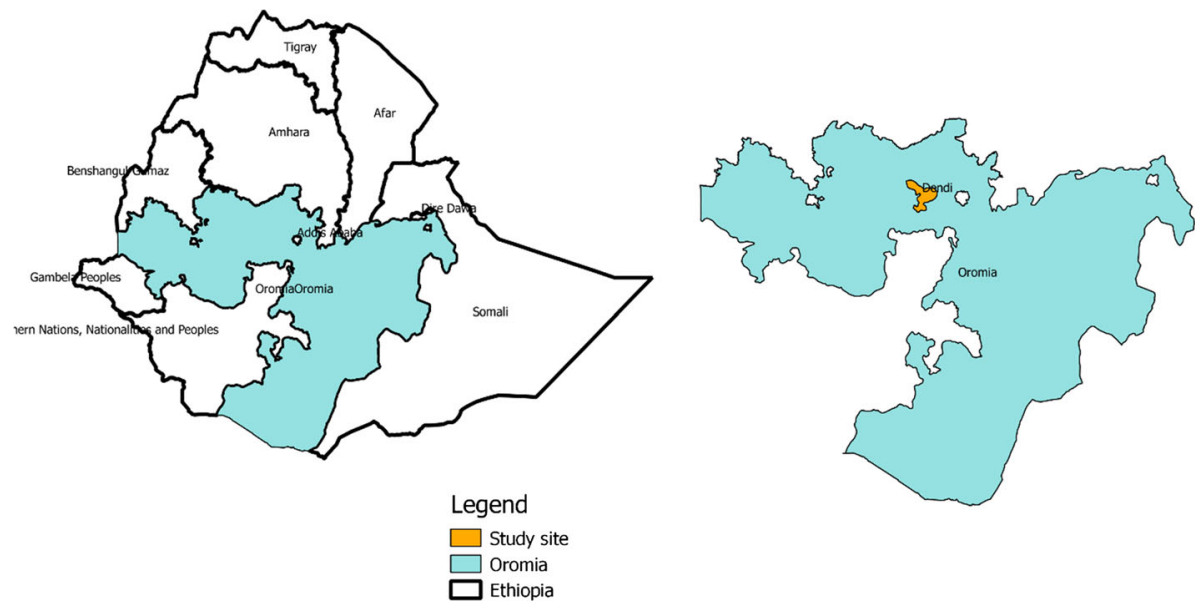

Fig. 1 Map of the study site

implement participatory forest management (PFM) in collaboration with FARM-Africa (British-based international NGO) (Gobeze et al. 2009; Ameha et al. 2014). With the implementation of PFM, the forest in the study area was demarcated and allocated to 12 forest user groups (FUGs), 8 of which have already become forest users cooperatives (FUCs) since 2011.2

These FUGs (or FUCs) were organized on voluntary bases where forest-adjacent communities willing to participate in the community forest management became members by purchasing shares from the FUGs/FUCs. The groups are vested with the usufruct rights and responsibility to manage and maintain the community forest in their blocks. They craft their own administration and management rules as stipulated in the forest management plan signed by the FUGs and the local government representatives (Rural Land and Natural Resource Administration office (RLNRAO) of Dandi district). Out of the 12 FUGs in the study area, 8 FUGs/FUCs were randomly selected for this study.

Out of the eight sample FUGs (FUCs), four have only natural forest while the remaining four have both natural and plantation forest (see Table 3 in the "Appendix"). The advantage of managing plantation forest is that the cooperatives can sell timber from the plantation forest in consultation with the district-level administration (RLNRAO of Dandi district). According to the forest administration plan of FUGs, it is not possible to sell timber from natural forest. Thus, the larger the plantation forest the groups or cooperatives manage, the larger would be their gain from the sale of timber products. Twenty per cent of the money from the sale of timber is used for financing the activities of the groups/cooperatives, $30 \%$ of the money goes to the government as tax, $30 \%$ is divided among the

\footnotetext{
${ }^{2}$ While the FUGs do not have legal status in Ethiopian law, the FUC can act as legal entity under any condition. Further, while FUCs can own their own business, the FUGs cannot. The FUGs are established only for the purpose of managing the community forest. By law, FUGs are organized only for forest conservation and hence cannot enter into legally binding contracts. In addition, for the groups to sell shares, divide dividends, engage in other businesses than protecting the forest, and to sue someone who encroaches illegally in their forest, they have to be organized as cooperatives (Cooperative Societies Proclamation No. 147/1998). To assume the status of a legal entity, the FUGs have to be upgraded to the level of FUCs.
} 
members based on the shares they hold and the remaining $20 \%$ is used for community development projects (PFMP News Letter 2005). ${ }^{3}$

The participatory forest management programme also has a package of livelihood activities with the aim of decreasing illegal and unsustainable forest use by diversifying the sources of livelihood of the forest dependent communities. The livelihood improvement activities include both non-forest-based livelihood activities (such as poultry development, cattle herding, vegetable gardening, etc.) and forest-based livelihood activities (such as beekeeping, agroforestry, medicinal plant, timber, etc.).

The members of the FUGs are mainly responsible for two activities.

1. Maintenance and rehabilitation of the forest: the members plant trees in their forest plot and engage in nursery activities. In most of the FUGs, maintenance activities are conducted twice a year.

2. Patrolling through their community forest (Monitoring): it is clearly stated in the FUGs administration document that the community members contribute labour to patrol through the forest block of their FUG. Every day two male members of the FUGs are required to patrol and the patrols are assigned in rotation. Punishment in cases of in compliance with the rules of the groups would be decided by the executive committee of the forest user groups. This study aims at investigating how the contribution of labour by households for patrolling through the community forest is influenced by their dependence on the community forest for their livelihoods.

\subsection{Sources of data}

The study mainly used primary data collected through household survey. A structured questionnaire was used to collect data from 200 households randomly selected from 8 FUGs/FUCs. To select the sample households, the study utilized two-stage random sampling technique. In the first stage, simple random sampling technique was used to select the FUGs. In the second stage, random sampling technique was used to select sample households from the 8 FUGs selected in the first stage. Probability proportional to size sampling method was used to enhance the representativeness of the sample. Most of the sample respondents were household heads, but in few cases representatives of the household heads with sufficient knowledge about the household characteristics were interviewed.

Data were collected on the characteristics of the household and household heads, household income sources and others. In the questionnaire, particular emphasis was given to the contribution of the community forest to household income through home consumption and sales. The questionnaire was finalized incorporating feedbacks from the pilot survey conducted to test the relevance, consistency and adequacy of the questionnaire. Out of the 200 questionnaires distributed to the sample respondents, 10 were discarded due to incomplete information.

\subsection{Methods of analysis}

To investigate the role of forest dependence on households' labour contribution to community forest management, both descriptive statistics and mixed effect linear regression

${ }^{3}$ FARM Africa and SOS Sahel Ethiopia. Participatory forest management (FMP) News Letter. September, 2005. Vol. 1 Issue 5. 
models were used. Mixed effects models were used to account for the clustering of observations at FUG level.

The dependent variable in the regression analysis was the households' labour contribution to collective action as a proportion of the maximum required labour per household for patrolling through the community forest block. This proportion was obtained by dividing the reported labour hours contributed by households by the maximum required per household per year. To obtain the maximum contributable labour hours per year per member households, the number of days in a year (365 days) were divided by the number of member households, and multiplied the quotient by 16 [ $2 * 8$ (because every day two members of the FUGs are required to patrol and $8 \mathrm{~h}$ per day assumed)]. The proportion was used as a proxy to the level of the households' cooperation in collective action. The advantage of using the labour contribution as a proportion of the maximum contributable is that the absolute labour hours contribution may not reflect the true level of households' cooperation as the maximum contributable labour hours required per household could vary depending on the number of the FUG members. The robustness of the results for the definition of the dependent variable was checked by using the absolute number of labour hours reported by households as a response variable. Moreover, Tobit, censored least absolute deviation (CLAD), quantile regression models and instrumental variables models were used to check for the robustness of the results for model selection, and the major findings remained similar (see Tables 5, 6 in the "Appendix").

The important predictor variable in the study is households' dependence on community forest for livelihood, which was measured as the amount of income the households derived from community forest divided by total annual household income. In principle, there could be endogeneity between the dependent variable and community forest dependence. Households with more contribution to collective action might be those households obtaining more resources from the forest, and those households who drive more resources from the community forest might be willing to contribute more, which may make simple linear regression models inconsistent (Maddala 1983). Thus, the instrumental variables (IV) model based on two-stage least squares (2SLS) method was used to check for the severity of the endogeneity problem. Distance from the forest block to the household homestead was used as an instrument as the variable was strongly correlated with forest dependence but had no significant effect on the dependent variable (i.e. labour contribution to collective action). In addition, statistical test shows that the instrument is relevant and strong $(F=21.99, p=0.0000)$. But the endogeneity test shows that endogeneity was not a problem in the data [Durbin $\chi^{2}(1)=0.326537 \quad(p=0.5677)$; Wu-Hausman $F(1,176)=0.302997(p=0.5827)$. This result is not surprising given that in the study area the members of the forest user groups are assigned in rotation, and there is no rule that requires households driving more resources from the forest to contribute more labour for patrolling through the community forest. Finally, drawing on the related literature, gender and education level of the household head, farm size, livestock ownership, distance from market centre, membership to local organizations and non-forest income were included as control variables (Lise 2000; Bardhan et al. 2007; Coulibaly-Lingani et al. 2011; Mwangi et al. 2011; Bisung et al. 2014; Fischer and Qaim 2014; Dash et al. 2016). The VIF test confirmed that there was no serious multicollinearity problem among the explanatory variables (maximum individual $\mathrm{VIF}=2.17$, Minimum $=1.04$, Mean VIF $=1.38$ ). 


\section{Results and discussion}

\subsection{Characteristics of sample households}

Majority of the sample respondents (83\%) were male, while only $17 \%$ were female. The average household size ${ }^{4}$ of the sample respondents was 6 , and the respondents, on average, were 45 years old. The mean education level of the sample household heads was 3.19 years. A significant proportion of the sample respondents $(41.6 \%)$ had no formal education, while $53.7 \%$ of the sample respondents had primary education and only $4.6 \%$ of the sample respondents had high school education. A small portion of the sample respondents had post high school education $(0.1 \%$ ) (see Table 4 in the "Appendix"). Over $94 \%$ of the sample respondents were born in the study area. In the sample, the dominant ethnic group was Oromo, which accounts for $88 \%$ of the sample respondents, followed by Amehara (6\%), Gurage (5\%) and other ethnic groups constituting only $1 \%$ of the sample. The dominance of Oromo ethnic group is not unexpected as the study was conducted in the Oromia regional state.

Mixed agriculture is the main economic activity in the study area from which almost all of the sample households derived their livelihoods. Most of the sample households derived their livelihoods mainly from subsistence agriculture (composed of crop production and livestock husbandry) and forest products from community forest. In addition, agriculture is the most important source of employment. The results show that the average annual income of the sample households was ETB 14,336.085 and was obtained from different sources including forest products, crop production, livestock, wage employment, transfer payments and others (see Fig. 2). On average, forest resources contribute $38.2 \%$ of the households' annual income, while mixed agriculture from crop production and livestock herding accounts for $51 \%$ of the total household annual income. The remaining $10.8 \%$ of the household annual income is contributed by wage employment, self-employment, transfer payments and other sources. Interestingly, community forest contributes more to the annual income of the households from FUGs with plantation forest $(41 \%)$ compared to that of the households from FUGs without plantation forest (36\%) $(n=190 ; t=-2.0127$; $p=0.0456$ ). This is not unexpected given that timber sale is allowed for only FUGs with plantation forest in the study area.

The major part of the household income comes from own consumption of household production. For example, only $15 \%$ of crop produced was sold out in the study area. In addition, the households sold out only $5 \%$ of the forest products they have collected from their community forest, and only $10 \%$ of the livestock income comes from the sale of live animals and animal products. This suggests that the study area can be characterized by subsistence agriculture and related economic activities mainly driven by own consumption of the households' production.

From group discussions, it was established that land holdings and livestock ownership are the common wealth indicators in the study area as it is common in rural Africa (Bationo et al. 2007). The farm size owned by sample households ranges from 0 to 10 ha, with the average farm size of 1.78 ha per household. While almost $6 \%$ of the sample respondents do not own farmland, around $39 \%$ of the sample households own less than or equal to 1 ha of

\footnotetext{
4 A household in this case includes all members that share consumption of food and non-food items. Moreover, it includes workers and servants if they have stayed together in the same household at least for half a year.

${ }^{5}$ ETB is Ethiopian legal currency (Birr) and the exchange rate at the time of the survey was 1 ETB $=0.042$ Euro $=0.061$ USD.
} 


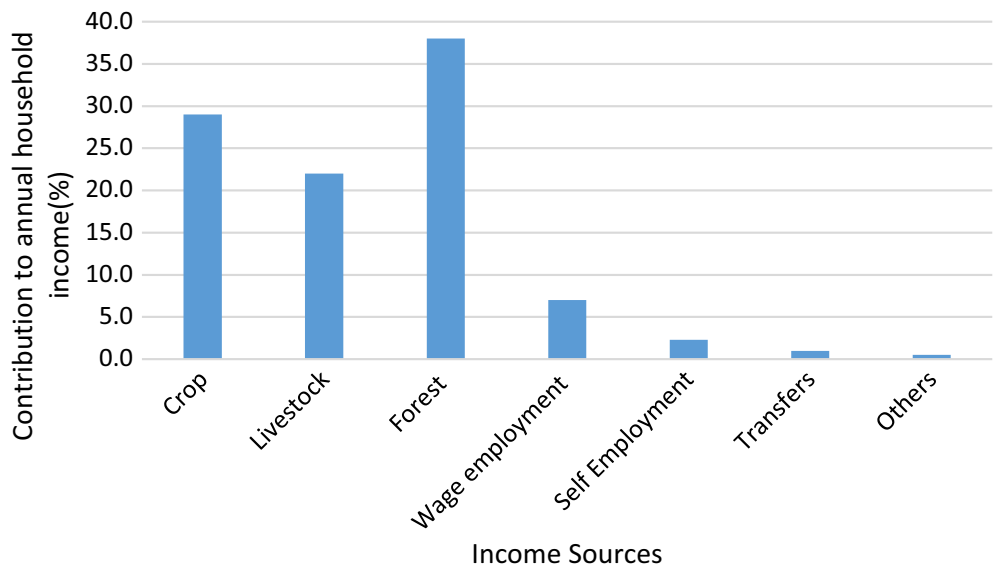

Fig. 2 Sources of household income (as $\%$ of the total annual income)

land, and only a small proportion of the sample households own farmland greater than 5 ha $(2.6 \%)$. Majority of the sample respondents $(75 \%)$ own less than 2 ha of arable land. On the other hand, only $25 \%$ of the households own $46 \%$ of the total arable land of the sample households, showing that there is high inequality in farmland holding in the study site.

Table 1 shows the characteristics of the sample households based on the farm size they own. The bottom quartile of the sample households (with the average farm size of 0.337 ha) is relatively income poor and earn annual income of ETB 10,939.89. This group of households was found to depend heavily on community forest for livelihood and derived about $46 \%$ of their annual income from forest products. Moreover, they own small amount of livestock as shown by low value of TLU (only 2.76). On the other hand, the top quartile of the sample households, on average, own 4.32 ha and earn relatively higher annual income (ETB 21,091.15), which is $93 \%$ higher than the amount earned by the bottom $25 \%$. The top $25 \%$ of the sample households are relatively less dependent on forest products and own high amount of livestock. Nonetheless, the results show that all households (whether they own larger or smaller farm size), on average, depended substantially on community forest for their livelihoods.

\subsection{Forest dependence and households' contribution to collective action}

\subsubsection{Descriptive statistics}

In the study area, forest income mainly comes from collection of firewood (ETB 3074.41), inputs for local drinks and handcrafts (ETB 2430.35), harvesting of forest products for own house and fence construction (ETB 2101.64), farm implements (ETB 1331.58), forestrelated employment (ETB 919.86) and others (ETB 1583.13).

According to the administrative rules of the participatory forest management (PFM) in the study site, the members of the FUGs patrol through their community forest block to control illegal harvest. Every day two guards from the members are assigned to patrol through their forest block in rotation. It was found that, on average, sample households spent $32 \mathrm{~h}$ per year on patrolling through their community forest, which is only $50 \%$ of the required contributable labour hours per household. The number of hours spent on patrolling in relation to the maximum varies from household to household. While some 
Table 1 Characteristics of sample households by farm size

\begin{tabular}{lcccc}
\hline & \multicolumn{3}{l}{ Quartiles of households by land holding } \\
\cline { 2 - 5 } & Bottom 25\% & $25-50 \%$ & $50-75 \%$ & Top 25\% \\
\hline Farm size (in ha) & 0.337 & 1.132 & 1.855 & 4.223 \\
Annual income (in ETB) & $10,939.89$ & $11,078.86$ & $14,374.33$ & $21,091.15$ \\
TLU (tropical livestock unit) & 2.76 & 3.979 & 3.985 & 6.803 \\
Forest dependence (as \% of total income) & 45.80 & 42.20 & 38.80 & 30.80 \\
\hline
\end{tabular}

households contributed only $14 \%$ of the maximum required, others contributed as much as $97 \%$ of the required amount.

Based on the farmland holdings, the bottom $25 \%$ of the households spent, on average, $33.27 \mathrm{~h}$ per annum constituting $54.78 \%$ of the total labour hours required from an average household, while the top $25 \%$ spent only 24.79 h (i.e. only $34.61 \%$ of the required amount) (see Fig. 3). In general, there is a negative and significant correlation between the farm size and labour contribution for patrolling (Spearman's rho $=-0.3011 ; p=0.000$ ).

\subsubsection{Empirical model results}

The primary interest in this section is to examine the impact of forest dependence on households' contribution to collective action for the management of community forest. Households' dependence on community forest is measured as the amount of income the households derive from community forest divided by total annual household income. The results show that all the sample respondents have derived some part of their income from forest resources ranging from 4 to $78 \%$ of their annual household income (on average $38.2 \%$ ). This high dependence of sample households on community forest is not unexpected given that the communities are typical community forest users. Further, studies have shown that in other parts of rural Ethiopia and Africa, communities substantially depend on forest resources. For example, Babulo et al. (2008) and Mamo et al. (2007) reported that communities from different parts of rural Ethiopia drive around $27 \%$ and $39 \%$ of their income from forest resources. Similarly, Appiah et al. (2009) reported that forest

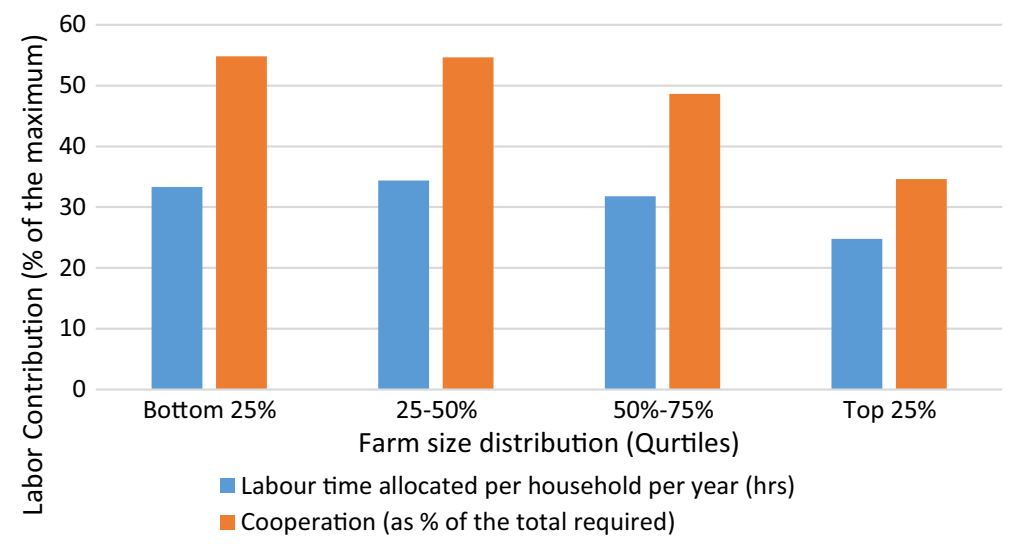

Fig. 3 Labour time allocation to collective action and farm size owned by households 
income accounts for $38 \%$ of total household income in rural Ghana. Moreover, Angelsen et al. (2014), based on data from 24 developing countries, reported that $28 \%$ of the household income comes from resources freely obtained from the environment.

The Spearman's correlation coefficient shows that the degree of dependence on forest commons is positively and significantly related to patrolling efforts (Spearman's rho $=0.4247 ; p=0.000$ ). These findings were corroborated by regression results obtained from mixed effect linear regression model (Table 2).

The results in Table 2 show that the importance of the community forest as a source of households' livelihood has a positive and strong impact on their level of cooperation in contributing labour for patrolling through the community forest. Households with high dependence on forest products from community forest contributed more labour for patrolling through their community forest compared to households that depended less on community forest for their

Table 2 Results from mixed effects linear regression model

Dependent variable: the ratio of labour contributed by households to maximum required per household

\begin{tabular}{ll}
\hline Forest dependence & $27.01^{* * *}$ \\
& $(2.66)$ \\
Age (in years) & 0.0447 \\
& $(0.43)$ \\
Gender (male $=1$ ) & 2.847 \\
Education (in years) & $(0.71)$ \\
& -0.440 \\
Farm size (in ha) & $(-1.13)$ \\
& $-1.866^{*}$ \\
Livestock (in TLU) & $(-1.67)$ \\
Ln (non-forest income) & -0.256 \\
& $(-0.62)$ \\
Number of male adults & -0.532 \\
Distance from market centre & $(-0.27)$ \\
& $5.701^{* * *}$ \\
Number of local organizations & $(5.07)$ \\
Committee membership (yes $=1)$ & 0.785 \\
Constant & $(0.38)$ \\
Random effect & $2.768 *$ \\
$N$ & $(1.64)$ \\
\hline
\end{tabular}

For definition of variables see "Appendix"

$Z$ statistics in parentheses; * $p<0.1$; ** $p<0.05$; *** $p<0.01$ 
livelihood. This shows that resource dependence for livelihood significantly affects the success of collective action for community management of the commons by enhancing cooperation among the members. Thus, it can be argued that in situations where resource users substantially depend on the commons, collective action is more likely to be successful (Wade 1989; Lise 2000; Heltberg 2001; Dietz et al. 2003; Kumar and Palanisami 2009).

The availability of adult men labour in the household was found to have a positive and significant effect on labour contribution for patrolling. Households with more men members were found to contribute more for collective action. This is not unexpected as the labour contributed for patrolling through the community forest is only that of men, which would depend on the availability of adult men labour in the household. In addition, participation in local organizations had positive and significant effect on households' contribution to collective action. Households headed by individuals participating in more local organizations contributed more to the collective action compared to households headed by individuals who participated in fewer local organizations. This may suggest that prior experience with other local organizations may promote contribution to collective action by strengthening the social capital of the local communities (Bisung et al. 2014).

\section{Conclusion}

The study investigated the role of households' dependence on community forest for their livelihood on their contribution to the management of community forest. It was found that the contribution of the community forest to the livelihood of the households had a positive and strong impact on their labour contribution to patrolling through their community forest. More dependence on forest products from the community forest leads to more contribution to collective action for the management of the community forest. This suggests that resource dependence for livelihood significantly affects the success of the community management of the common pool resource in general, which is in line with some studies in the literature (e.g. Wade 1989; Lise 2000; Heltberg 2001; Dietz et al. 2003; Kumar and Palanisami 2009). The role the community forest plays in the livelihood of the local communities could have two opposing effects on the success of community-based forest management. On the one hand, dependence on the resources from the community forest may increase the value the local communities attach to the community forest, which in turn may enhance their contribution to collective action. On the other hand, the heavy dependence on the forest products may undermine the success of the community management by leading to the degradation of the forest resources. The main emphasis of this study, however, is the former one, and the results show that resource dependence enhances the success of community management by increasing the households' contribution to the management of community forest. The results also show that the availability of more adult men in the household has a positive and significant effect on the labour contribution of the households to collective action. In general, the findings of the study underline that in situations where community forest plays an important role in the livelihood of the households, the local communities are more likely to contribute more to the collective action for the management of the community forest. This suggests that policy makers should make an effort to understand the importance of the community forest for the livelihood of the local communities before implementing the participatory forest management programme.

Acknowledgements Open access funding provided by Max Planck Society. I feel greatly indebted to the financial support obtained from DAAD (Deutscher Akademischer Austausch Dienst) for the study. 
Open Access This article is distributed under the terms of the Creative Commons Attribution 4.0 International License (http://creativecommons.org/licenses/by/4.0/), which permits unrestricted use, distribution, and reproduction in any medium, provided you give appropriate credit to the original author(s) and the source, provide a link to the Creative Commons license, and indicate if changes were made.

\section{Appendix}

See Tables 3, 4, 5, 6 and 7 .

Table 3 Characteristics of the sample FUGs (FUCs). Source: Office documents of Chilimo-Gaji Community forest users union, 2011

\begin{tabular}{|c|c|c|c|c|c|c|c|}
\hline \multirow[t]{2}{*}{ Name } & \multicolumn{3}{|c|}{ Number of members } & \multicolumn{3}{|c|}{ Forest size (ha) } & \multirow{2}{*}{$\begin{array}{l}\text { Organized as } \\
\text { FUC/FUG }\end{array}$} \\
\hline & Male & Female & Total & Natural forest & Plantation forest & Total & \\
\hline Mesalemia & 88 & 31 & 119 & 664 & 246 & 910 & FUC \\
\hline Gaji & 221 & 51 & 272 & 839 & 48 & 887 & FUC \\
\hline Chilimo & 114 & 24 & 138 & 596 & 99 & 695 & FUC \\
\hline Goben & 69 & 14 & 83 & 188 & 0 & 188 & FUC \\
\hline Galessa & 139 & 48 & 187 & 384 & 0 & 384 & FUC \\
\hline Dano Sangota & 115 & 16 & 131 & 316 & 11 & 327 & FUC \\
\hline Kersa Alati & 74 & 8 & 82 & 176 & 0 & 176 & FUG \\
\hline Yubdo Gerersa & 85 & 11 & 96 & 148 & 0 & 148 & FUC \\
\hline
\end{tabular}

Based on the size of the forest, Mesalemia-FUC stands the first with 910 ha of forest; $73 \%$ of which is natural forest and the remaining $27 \%$ is plantation forest (see Table 3 in the "Appendix"). The second largest FUC is Gaji (887 ha), with most of the forest being natural forest (95\%) and only 5\% of plantation forest. The smallest forest was managed by Yubdo Gerersa FUG (148 ha)

Table 4 Definition of important variables

\begin{tabular}{|c|c|c|c|}
\hline Variable name & Description of the variable & Mean & SD \\
\hline Household size & The size of the household (in number) & 6.36 & 2.08 \\
\hline Age & The age of the household head in years & 45.08 & 12.53 \\
\hline Gender & $\begin{array}{l}\text { Dummy variable for the gender of the household head and assumes } 1 \\
\text { if the household head is male and } 0 \text { otherwise }\end{array}$ & 0.83 & 0.38 \\
\hline Education & The level of education attained by the household head in years & 3.19 & 2.96 \\
\hline Farm size & The size of the farm owned by the household (in ha) & 1.78 & 1.53 \\
\hline Ethinicity & $\begin{array}{l}\text { Dummy variable for the ethnicity of the household head. It assumes } 1 \\
\text { if the household head is Oromo and } 0 \text { otherwise }\end{array}$ & 0.88 & \\
\hline Forest dependence & $\begin{array}{l}\text { Forest dependence measured as the ratio of forest income to the total } \\
\text { income of the household }\end{array}$ & 38.20 & 16.22 \\
\hline $\begin{array}{l}\text { Adult male } \\
\text { members }\end{array}$ & The number of adult men in a household & 1.20 & 1.11 \\
\hline $\begin{array}{l}\text { Distance from } \\
\text { market centre }\end{array}$ & $\begin{array}{l}\text { Measured by the distance from the homestead of the household to the } \\
\text { nearest local market centre; in our case, the distance from the } \\
\text { household to the town of Ginchi (in KMs) }\end{array}$ & 2.31 & 1.50 \\
\hline $\begin{array}{l}\text { Number of local } \\
\text { organizations }\end{array}$ & $\begin{array}{l}\text { The number of local organizations to which the household head is a } \\
\text { member }\end{array}$ & 1.86 & 0.97 \\
\hline
\end{tabular}




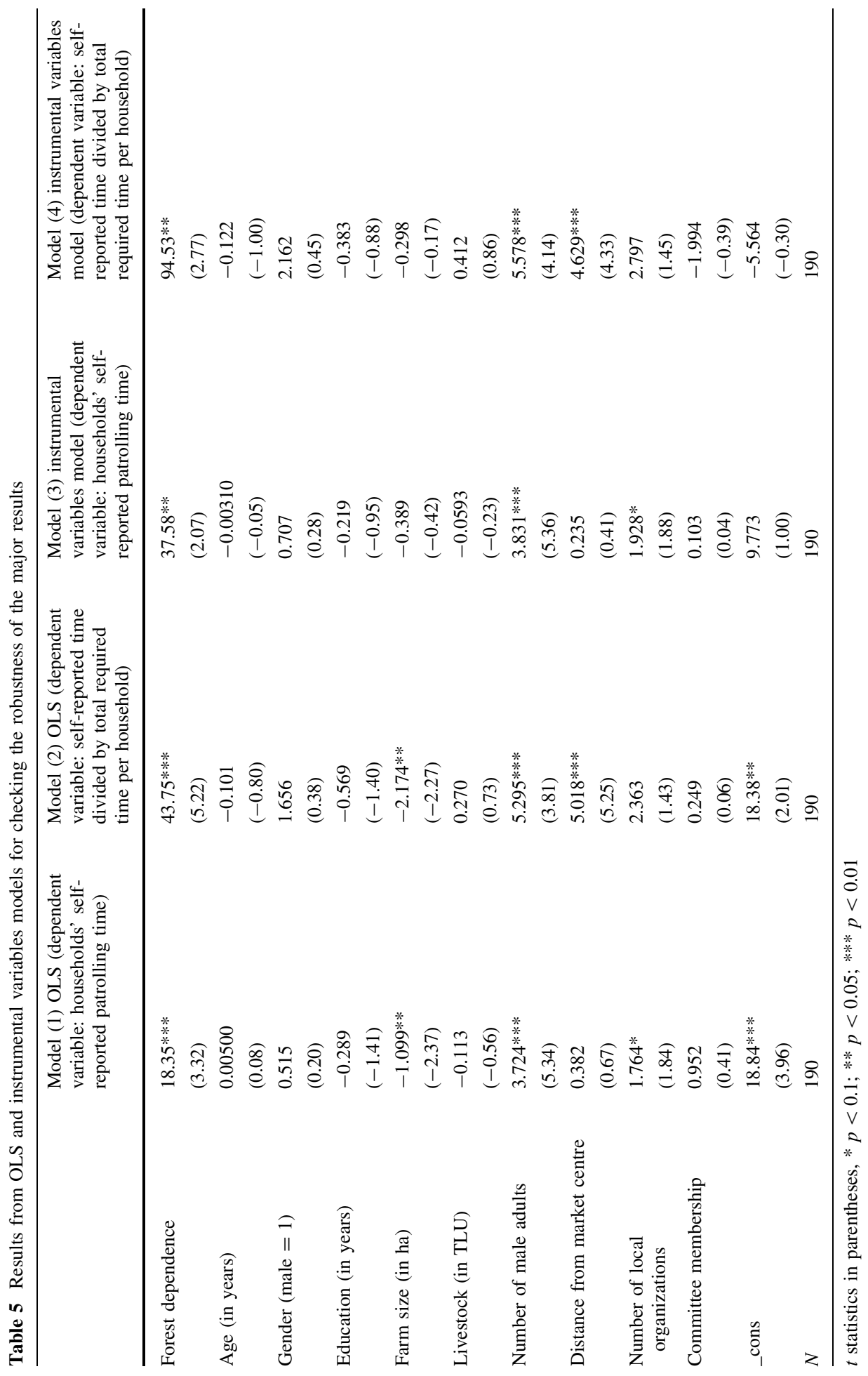




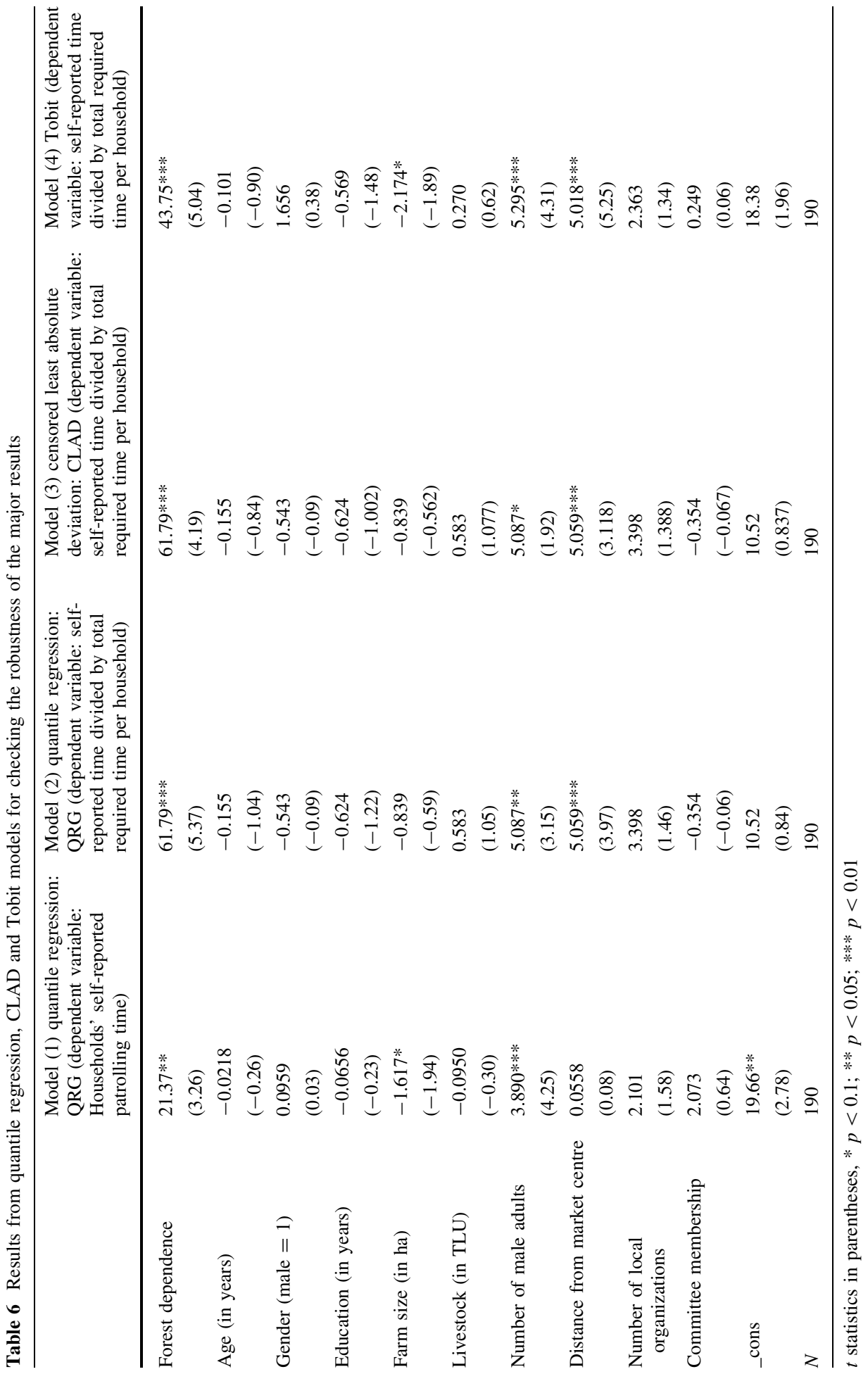


Table 7 Different models for checking the sensitivity of the major findings for the inclusion and exclusion of control variables in the model

\begin{tabular}{|c|c|c|}
\hline & $\begin{array}{l}\text { Model (1) } \\
\text { Without control variables }\end{array}$ & $\begin{array}{l}\text { Model (2) } \\
\text { With control variables }\end{array}$ \\
\hline Forest dependence & $\begin{array}{l}29.52 * * * \\
(3.39)\end{array}$ & $\begin{array}{l}26.60 * * * \\
(2.60)\end{array}$ \\
\hline Household size & & $\begin{array}{l}0.786 \\
(1.44)\end{array}$ \\
\hline Age & & $\begin{array}{l}0.0390 \\
(0.39)\end{array}$ \\
\hline Gender & & $\begin{array}{l}1.778 \\
(0.45)\end{array}$ \\
\hline Education level & & $\begin{array}{l}-0.616^{*} \\
(-1.73)\end{array}$ \\
\hline Farm size & & $\begin{array}{l}-2.037 * * \\
(-1.99)\end{array}$ \\
\hline Livestock (in TLU) & & $\begin{array}{l}-0.253 \\
(-0.63)\end{array}$ \\
\hline Ln (non-forest income) & & $\begin{array}{l}-1.471 \\
(-0.72)\end{array}$ \\
\hline Number of male adults & & $\begin{array}{l}5.731 \text { *** } \\
(5.18)\end{array}$ \\
\hline Distance from market centre & & $\begin{array}{l}1.017 \\
(0.52)\end{array}$ \\
\hline Number of local organizations & & $\begin{array}{l}2.738 * \\
(1.65)\end{array}$ \\
\hline Committee membership $($ yes $=1$ ) & & $\begin{array}{l}0.900 \\
(0.22)\end{array}$ \\
\hline Constant & $\begin{array}{l}31.23 * * * \\
(5.36)\end{array}$ & $\begin{array}{l}19.82 * \\
(1.90)\end{array}$ \\
\hline$N$ & 190 & 190 \\
\hline
\end{tabular}

$t$ statistics in parentheses, $* p<0.1 ; * * p<0.05 ; * * * p<0.01$

\section{References}

Adhikari, B. (2005). Poverty, property rights and collective action: Understanding the distributive aspects of common property resource management. Environment and Development Economics, 10(1), 7-31.

Adhikari, B., Di Falco, S., \& Lovett, J. C. (2004). Household characteristics and forest dependency: Evidence from common property forest management in Nepal. Ecological Economics, 48(2), 245-257.

Ameha, A., Larsen, H. O., \& Lemenih, M. (2014). Participatory forest management in Ethiopia: Learning from pilot projects. Environmental Management, 53(4), 838-854.

Andrade, G., \& Rhodes, J. (2012). Protected areas and local communities: An inevitable partnership toward successful conservation strategies? Ecology and Society, 17(4), 14. 
Angelsen, A., Jagger, P., Babigumira, R., Belcher, B., Hogarth, N. J., Bauch, S., et al. (2014). Environmental Income and Rural Livelihoods: A Global-Comparative Analysis. World Development, 64(S1), S12-S28

Appiah, M., Blay, D., Damnyag, L., Dwomoh, F. K., Pappinen, A., \& Luukkanen, O. (2009). Dependence on forest resources and tropical deforestation in Ghana. Environment, Development and Sustainability, 11(3), 471-487.

Babulo, B., Muys, B., Nega, F., Tollens, E., Nyssen, J., Deckers, J., et al. (2008). Household livelihood strategies and forest dependence in the highlands of Tigray, Northern Ethiopia. Agricultural Systems, 98(2), 147-155.

Babulo, B., Muys, B., Nega, F., Tollens, E., Nyssen, J., Deckers, J., \& Mathijs, E. (2009). The economic contribution of forest resource use to rural livelihoods in Tigray, Northern Ethiopia. Forest Policy and Economics, 11(2), 123-131.

Bardhan, P., Ghatak, M., \& Karaivanov, A. (2007). Wealth inequality and collective action. Journal of Public Economics, 91(9), 1843-1874.

Bationo, A., Waswa, B., Kihara, J., \& Kimetu, J. (Eds.). (2007). Advances in integrated soil fertility management in sub-Saharan Africa: Challenges and opportunities. Dordrecht: Springer.

Bekele, M., \& Bekele, T. (2005). Participatory forest management in Ethiopia: Bonga and Chillimo: Final evaluation report. Addis Ababa: Oromia Regional State.

Bisung, E., Elliott, S. J., Schuster-Wallace, C. J., Karanja, D. M., \& Bernard, A. (2014). Social capital, collective action and access to water in rural Kenya. Social Science and Medicine, 119, 147-154.

Brechin, S. R., Wilshusen, P. R., Fortwangler, C. L., \& West, P. C. (2002). Beyond the square wheel: Toward a more comprehensive understanding of biodiversity conservation as social and political process. Society \& Natural Resources, 15(1), 41-64.

Cardenas, J.-C. (2000). How do groups solve local commons dilemmas? Lessons from experimental economics in the field. Environment, Development and Sustainability, 2(3-4), 305-322.

Charnley, S., \& Poe, M. R. (2007). community forestry in theory and practice: Where are we now? Annual Review of Anthropology, 36(1), 301-336.

Coulibaly-Lingani, P., Savadogo, P., Tigabu, M., \& Oden, P. C. (2011). Factors influencing people's participation in the forest management program in Burkina Faso, West Africa. Forest Policy and Economics, 13(4), 292-302.

Cox, M., Arnold, G., \& Tomás, S. V. (2010). A review of design principles for community-based natural resource management. Ecology and Society, 15(4), 38.

Dash, M., Behera, B., \& Rahut, D. B. (2016). Determinants of household collection of non-timber forest products (NTFPs) and alternative livelihood activities in Similipal Tiger Reserve, India. Forest Policy and Economics, 73, 215-228.

Dietz, T., Ostrom, E., \& Stern, P. (2003). The struggle to govern the commons. Science, 302(5652), 1907-1912.

FAO. (2010). Global forest resources assessment 2010 (Vol. 147). Rome.

FAO. (2015). Global forest resources assessment 2015. Rome.

Fischer, E., \& Qaim, M. (2014). Smallholder farmers and collective action: What determines the intensity of participation? Journal of Agricultural Economics, 65(3), 683-702.

Gatiso, T. T., \& Wossen, T. (2014). Forest dependence and income inequality in rural Ethiopia: Evidence from Chilimo-Gaji community forest users. International Journal of Sustainable Development and World Ecology, 22(1), 1-11.

Geissler, S., Hagauer, D., Horst, A., Krause, M., \& Sutcliffe, P. (2013). Biomass energy strategy: Ethiopia. Taunus: AMBERO Consulting Gesellschaft mbH.

Gibson, C. C., \& Marks, S. A. (1995). Transforming rural hunters into conservationists: An assessment of community-based wildlife management programs in Africa. World Development, 23(6), 941-957.

Gobeze, T., Bekele, M., Lemenih, M., \& Kassa, H. (2009). Participatory forest management and its impacts on livelihoods and forest status: The case of Bonga forest in Ethiopia. International Forestry Review, 11(3), 346-358.

Harrison, R. D. (2011). Emptying the forest: Hunting and the extirpation of wildlife from tropical nature reserves. BioScience, 61(11), 919-924.

Heltberg, R. (2001). Determinants and impact of local institutions. Environment and Development Economics, 6, 183-208.

Kapoor, I. (2001). Towards participatory environmental management? Journal of Environmental Management, 63, 269-279.

Kumar, D. S., \& Palanisami, K. (2009). An economic inquiry into collective action and household behaviour in watershed management. Indian Journal of Agricultural Economics, 64(1), 108-122.

Lise, W. (2000). Factors influencing people's participation in forest management in India. Ecological Economics, 34(3), 379-392. 
Maddala, G. S. (1983). Limited Dependent and Qualitative Variables in Econometrics, Econometric Society Monographs. Cambridge University Press, Cambridge.

Mamo, G., Sjaastad, E., \& Vedeld, P. (2007). Economic dependence on forest resources: A case from Dendi District, Ethiopia. Forest Policy and Economics, 9(8), 916-927.

Mohammed, A. J., \& Inoue, M. (2013). Forest-dependent communities' livelihood in decentralized forest governance policy epoch: Case study from West Shoa zone, Ethiopia. Journal of Natural Resources Policy Research, 5(1), 49-66.

Mwangi, E., Meinzen-dick, R., \& Sun, Y. (2011). Gender and sustainable forest management in East Africa and Latin. Ecology and Society, 16(1), 17-32.

Narain, U., Gupta, S., \& van't Veld, K. (2008). Poverty and resource dependence in rural India. Ecological Economics, 66(1), 161-176.

Ostrom, E. (1990). Governing the commons: The evolution of institutions for collective action. Cambridge: Cambridge University Press.

Ostrom, E. (1999). Self-governance and forest resources. Occational Paper, 62(20), 1-15.

Pagdee, A., Kim, Y., \& Daugherty, P. J. (2006). What makes community forest management successful: A meta-study from community forests throughout the world. Society \& Natural Resources, 19(1), 33-52.

Persha, L., Agrawal, A., \& Chhatre, A. (2011). Social and ecological synergy: local rule making, forest livelihoods, and biodiversity conservation. Science (New York, N.Y.), 331, 1606.

Rahut, D. B., Ali, A., \& Behera, B. (2015). Household participation and effects of community forest management on income and poverty levels: Empirical evidence from Bhutan. Forest Policy and Economics, 61, 20-29.

Schnegg, M., Bollig, M., \& Linke, T. (2016). Moral equality and success of common-pool water governance in Namibia. Ambio, 45(5), 581-590.

Sunderlin, W. D., Belcher, B., Santoso, L., Angelsen, A., Burgers, P., Nasi, R., et al. (2005). Livelihoods, forests, and conservation in developing countries: An overview. World Development, 33(9 SPEC. ISS.), 1383-1402.

Wade, R. (1988). Village republics: Economic conditions for collective action in South India. Cambridge University Press.

Wade, R. (1989). Village republics: Economic conditions for collective action in South India. Cambridge: Cambridge University Press.

Wang, S. W., Lassoie, J. P., \& Curtis, P. D. (2006). Farmer attitudes towards conservation in Jigme Singye Wangchuck National Park, Bhutan. Environmental Conservation, 33(2), 148-156.

Wells, M. P., \& McShane, T. O. (2004). Integrating protected area management with local needs and aspirations. AMBIO: A Journal of the Human. Environment, 33(8), 513-519.

West, P. C., \& Brechin, S. R. (1991). Resident peoples and national parks: Social dilemmas and strategies in international conservation. Tucson: University of Arizona Press.

Wunder, S., Angelsen, A., \& Belcher, B. (2014). Forests, Livelihoods, and Conservation: Broadening the Empirical Base. World Development, 64(S1), S1-S11.

Yang, W., Liu, W., Vina, A., Tuanmu, M.-N., He, G., Dietz, T., et al. (2013). Nonlinear effects of group size on collective action and resource outcomes. Proceedings of the National Academy of Sciences, 110(27), 10916-10921. 